\title{
Karakteristik Kemiskinan dan Penanggulangannya di Kabupaten Sidoarjo
}

\author{
1) SANADJIHITU SANGADJI, 2) TOTOK WAHYU ABADI, ${ }^{3)}$ LULUK FAUZIAH \\ 1) 3) Departemen Ilmu Administrasi Negara FISIP, Universitas Muhammadiyah, Jalan Majapahit 666 B Sidoarjo \\ 2) Departemen IImu Komunikasi FISIP Universitas Muhammadiyah Sidoarjo, Jalan Majapahit 666 B Sidoarjo \\ email: email: sansangadji@gmail.com, lulukfauz@yahoo.co.id; totokwahyu@umsida.ac.id
}

\begin{abstract}
This article aims to analyze and to describe the characteristics of poverty as well as reduction policies/programs in Sidoarjo Regency. The location of this exploratory study is conducted in Sidoarjo Regency. Basic argument is caused Sidoarjo Regency Regency has the lowest poverty rate in East Java as well as get pro poor award from Indonesian government in 2011 and 2012. The subjects of this study as many as thirty people with the key informants Vice Regent of Sidoarjo. Data is collected through interviews to all informants. Then its data is coded and analyzed through grounded analyzing techniques from Strauss and Corbin. The results show that poverty characteristic in Sidoarjo Regency is caused cultural in both rural and urban area. Implementation of existing poverty reduction programs are still not optimal and targeted.
\end{abstract}

Keywords: cultural poverty, structural poverty, poverty reduction, monitoring and evaluation

\begin{abstract}
Abstrak. Tulisan ini bertujuan untuk menganalisis dan menjabarkan karakteristik kemiskinan serta kebijakan dan program penanggulangannya di Kabupaten Sidoarjo. Lokasi penelitian eksploratif ini dilaksanakan di Kabupaten Sidoarjo. Argumentasi dasar yang digunakan karena Kabupaten Sidoarjo memiliki angka kemiskinan paling rendah di Jawa Timur serta pernah mendapatkan penghargaan pro poor award dari pemerintah RI pada tahun 2011 dan 2012. Subjek penelitian ini sebanyak tiga puluh orang dengan key informan Wakil Bupati Sidoarjo.Pengumpulan data dilakukan melalui interview kepada seluruh informant. Data yang terkumpul kemudian dikoding dan dianalisis dengan teknik penganalisisan grounded dari Strauss dan Corbin. Hasil penelitian menunjukkan bahwa kemiskinan di Kabupaten Sidoarjo lebih bersifat kultural baik di wilayah rural maupun urban (perkotaan). Pelaksanaan program penanggulangan kemiskinan yang ada selama ini masih belum optimal dan tepat sasaran.
\end{abstract}

Kata kunci: kemiskinan kultural, kemiskinan struktural, penanggulangan kemiskinan, monitoring dan evaluasi

\section{Pendahuluan}

Kemiskinan merupakan fenomena sosial-ekonomi yang tidak hanya melintas batas agama, tetapi juga suku dan kebangsaan. Karakteristik utamanya adalah rendahnya dan terbatasnya aksesibilitas dalam pemenuhan kebutuhan baik pangan, sandang, papan maupun pendidikan, kesehatan, dan hiburan. Fenomena tersebut tentu diperlukan penanganan dengan pendekatan yang sesuai karakteristiknya agar angka kemiskinan yang begitu tinggi menjadi berkurang. Jumlah masyarakat miskin di Kabupaten
Sidoarjo sejak tahun 2008 hingga 2013 terus mengalami penurunan (http://dprdsidoarjokab.go.id/pemkab-dan-dprd-bedadata-soal-angka-kemiskinan.html diakses tanggal 4 April 2014).

Pada 2008 jumlah masyarakat miskin sekitar 193.394 jiwa $(9,44 \%)$; tahun 2011 sebesar 7,45\%; dan tahun 2013 turun menjadi 6,97\% (136.300 jiwa) dari jumlah penduduk sebanyak dua juta lebih. Tingkat kemiskinan tersebut banyak terlokus di tiga kecamatan, yakni Jabon, Krembung, dan Krian. 
ANGGARAN DAN TINGKAT KEMISKINAN KABUPATEN SIDOARJOTAHUN 2009 s/d 2012

- Anggaran (Milyar rupiah) - $\quad$ Tingkat kemiskinan (\%)

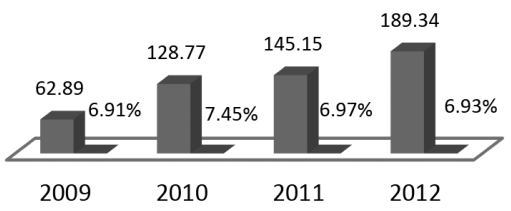

Sumber : Bappeda Kabupaten Sidoarjo, 2013

Strategi penanggulangan kemiskinan di Indonesia yang diatur dalam Peraturan Presiden Nomor 5 Tahun 2010 tentang Percepatan Penanggulangan Kemiskinan, menunjukkan bahwa Pemerintah Indonesia bersungguh-sungguh untuk menurunkan angka kemiskinan sesuai target MDGs pada Tahun 2015.

Strategi dan kebijakan penanggulangan kemiskinan yang diimplementasikan dalam suatu anggaran oleh pemerintah pusat maupun provinsi dan kabupaten/ kota untuk menurunkan angka kemiskinan dapat dikatakan cukup berhasil. Namun, keberhasilan pelaksanaan program penanggulangan kemiskinan di Indonesia selama ini hanya dilihat dari pencapain target kinerja atau angka-angka agregat kemiskinan yang mengalami penurunan setiap tahun.

Padahal, dalam anggaran berbasis kinerja, keberhasilan suatu program tidak hanya-dilihat dari pencapaian outcome atau impact, tetapi juga pencapaiannya secara efisien dan efektif. Yang terjadi selama ini, efisiensi dan efektifitas pelaksanaan program pembangunan termasuk pengentasan kemiskinan tidak dapat diukur, karena tidak dapat dibandingkan antara jumlah anggaran yang dikeluarkan untuk program penanggulangan kemiskinan dengan kinerja yang dicapai.Ini berarti bahwa perumusan perencanaan kebutuhan program dan anggaran untuk pengentasan kemiskinan diproyeksikan secara parsial dan tidak berdasar pada satu kerangka pengeluaran yang terintegrasi.

Pengentasan kemiskinan dengan menekan angka kemiskinan sekecil-kecilnya merupakan upaya yang harus dilakukan oleh semua komponen masyarakat dan pemerintah. Masyarakat yang mempunyai karsa (daya dan upaya) yang kuat adalah masyarakat yang mampu menekan angka kemiskinan sekecil-kecilnya (Muhardi,2000). Upaya Pemerintah Kabupaten Sidoarjo untuk menurunkan angka kemiskinan dengan mengalokasikan anggaran selama empat tahun terakhir juga sudah dilakukan. Bahkan anggaran yang dialokasikan selalu meningkat setiap tahunnya (Gambar 1).

Namun demikian, efisiensi dan efektivitas pelaksanaan program pengentasan kemiskinan tidak dapat diukur, karena tidak dapat dibandingkan antara jumlah anggaran yang dikeluarkan untuk program penanggulangan kemiskinan dengan kinerja yang dicapai.Pula capaian penurunan tingkat kemiskinan di Kabupaten Sidoarjo tidaklah cukup signifikan.

Secara teoretis, semakin tinggi alokasi anggaran untuk penanggulangan kemiskinan, semakin efektif kinerja anggaran tersebut untuk menurunkan angka kemiskinan. Karenanya, Fernanda (2002) dan Radin (2006) menyatakan bahwa akuntabilitas anggaran berbasis kinerja dalam penanggulangan kemiskinan dapat dilihat dari 1) penentuan dan pelaksanaan program, 2) aturan yang sesuai dengan proses dan prosedur, dan 3) hasil yang dicapai. Nilai - nilai yang harus dikedepankan dan diwujudkan dalam penanggulangan kemiskinan juga memperhatikan pencapaian yang efektif dan efisien (Peters, 1996; Rievenbark, 2004).

Berdasarkan identifikasi masalah tersebut, rumusan penulisan ini adalah menganalisis dan mendeskripsikan karakteristik kemiskinan, kebijakan dan penanggulangannya di Kabupaten Sidoarjo. Penelitian ini menjadi sangat penting karena beberapa permasalahan yang menjadi isu menarik tentang penanggulangan kemiskinan ada yang masih belum efektif dan efisien. Secara nasional, capaian penanggulangan kemiskinan masih berkisar 30,02\% dari jumlah penduduk Indonesia atau 12,49 juta jiwa hingga 2015. Hal tersebut merupakan tantangan terbesar yang harus diwujudkan guna mencapai angka maksimal 15,5\% tahun 2015 sebagai bagian dari tujuan Millenium Development Goals (Kementrian PPN/ Bappenas, 2010).

$$
\text { Program-program prioritas }
$$
penanggulangan kemiskinan yang terintegrasi dalam Rencana Pembangunan Jangka Menengah/Panjang (RPJPM/P) masih belum mampu menurunkan angka kemiskinan secara efektif dan menyentuh pada kebutuhan dasar masyarakat dalam jangka waktu menengah ataupun panjang. Penanggulangan kemiskinan oleh pemerintah sekadar kebijakan kemurahan hati (karikatif), 
kegiatan pinggiran, tidak memberdayakan masyarakat, serta masyarakat hanya sebagai objek sasaran. Penanggulangan kemiskinan hanya berorientasi pada aspek ekonomi dan proyek daripada aspek multidimensional. Dalam penanganan kemiskinan, pemerintah masih bertindak sebagai penguasa yang kerapkali turut campur tangan terlalu luas dalam kehidupan orang-orang miskin. Kebijakan penanggulangan kemiskinan bersifat sementara, seiring sejalan dengan habisnya kegiatan proyek. Bias birokrasi dan lemahnya posisi penduduk miskin. Kecenderungan sentralisasi dalam penggunaan dana. Permasalahan tersebut menunjukkan bahwa terdapat kesenjangan antara realitas dan yang diharapkan.

Kemiskinan tidak hanya berkaitan dengan dimensi ekonomi tetapi juga dimensi lain seperti hak pangan, papan, kesehatan, pendidikan, pekerjaan, dan sebagainya. Definisi kemiskinan menurut Konferensi Dunia untuk Pembangunan Sosial seperti yang dikutip Sahdan (2005) adalah:

"rendahnya tingkat pendapatan dan sumber daya produktif yang menjamin kehidupan berkesinambungan; kelaparan dan kekurangan gizi; rendahnya tingkat kesehatan; keterbatasan dan kurangnya akses pada pendidikan dan layananlayanan pokok lainnya; kondisi tak wajar akibat penyakit yang terus meningkat; kehidupan bergelandang dan tempat tinggal yang tidak memadai; lingkungan yang tidak aman, serta diskriminasi dan keterasingan sosial; dan dicirikan juga oleh rendahnya tingkat partisipasi dalam proses pengambilan keputusan dan dalam kehidupan sipil, sosial dan budaya.

Mengutip pendapat Ala, Noverman (2000) menjelaskan bahwa kemiskinan terdiri dari beberapa aspek, yaitu:

1) Kemiskinan multidimensional. Artinya, karena kebutuhan manusia itu bermacam-macam, kemisikinan pun memiliki banyak aspek. Dilihat dari perspektif kebijakan, kemiskinan meliputi aspek primer dan sekunder. Yang termasuk aspek primer diantaranya adalah miskin terhadap aset-aset, organisasi sosial politik, pengetahuan dan keterampilan. Sedangkan aspek sekunder berupa miskin akan jaringan sosial, sumber-sumber keuangan dan informasi. Akhirnya, dimensi ini termanifestasikan dalam bentuk kekurangan gizi, air, perumahan yang tidak sehat, perawatan kesehatan yang kurang baik, dan begitu juga dengan pendidikannya. 2) Aspek-aspek kemiskinan saling berkait, baik langsung maupun tidak langsung. Hal ini berarti bahwa kemajuan dan kemunduran pada salah satu aspek dapat mempengaruhi kemajuan dan kemunduran pada aspek lainnya. 3) Bahwa yang miskin adalah manusianya, baik secara individu atau kolektif. Sering didapati istilah kemiskinan pedesaan (rural poverty), kemiskinan perkotaan (urban poverty). Namun demikian, bukan berarti desa atau kota yang mengalami kemi- skinan, tetapi orang-orang atau penduduk (manusianya) yang menderita miskin.

Indikator kemiskinan yang dikeluarkan oleh BAPPENAS mempunyai makna yang relatif luas, yaitu dari berbagai sisi kebutuhan kehidupan, antara lain adalah; (1) terbatasnya kecukupan dan mutu pangan; (2) terbatasnya akses dan rendahnya mutu layanan kesehatan; (3) terbatasnya akses dan rendahnya mutu layanan pendidikan; (4) terbatasnya kesempatan kerja dan berusaha; (5) lemahnya perlindungan terhadap aset usaha, dan perbedaan upah; (6) terbatasnya akses layanan perumahan dan sanitasi; (7) terbatasnya akses terhadap air bersih; (8) lemahnya kepastian kepemilikan dan penguasaan tanah; (9) memburuknya kondisi lingkungan hidup dan sumberdaya alam, serta terbatasnya akses masyarakat terhadap sumber daya alam; (10) lemahnya jaminan rasa aman; (11) lemahnya partisipasi; (12) besarnya beban kependudukan yang disebabkan oleh besarnya tanggungan keluarga; (13) tata kelola pemerintahan yang buruk yang menyebabkan inefisiensi dan inefektivitas dalam pelayanan publik, meluasnya korupsi dan rendahnya jaminan sosial terhadap masyarakat (Sahdan, 2005).

Karakteristik kemiskinan dapat dilihat dari beberapa dimensi, yaitu kultural, struktural, dan sistemik (Kasim, 2006). Kemiskinan kultural adalah kemiskinan yang muncul karena faktor budaya atau mental masyarakat yang tidak memiliki etos kerja yang tinggi.Kemiskinan semacam ini termasuk kemiskinan yang paling mendalam dan bersifat kronis. Mereka menerima kondisi hidup sebagaimana adanya, penuh dengan kepasrahan, tidak memperlihatkan keinginan untuk keluar dari kondisi kemelaratan.

Kemiskinan struktural adalah kemiskinan yang terjadi karena adanya perbedaan struktur sosial.Perbedaan struktur sosial tersebut diakibatkan oleh kondisi struktur perekonomian yang timpang dalam masyarakat baik karena kebijakan ekonomi pemerintah, penguasaan faktor-faktor produksi oleh segelintir orang, monopoli, kolusi antara pengusaha dan pejabat pemerintah. Selama golongan kecil yang kaya raya masih menguasai berbagai segi kehidupan masyarakat, selama itu pula struktur sosial yang berlaku masih terus bertahan. Inti dari kemiskinan struktural adalah kemiskinan yang dibuat oleh manusia.Golongan yang termasuk dalam kategori ini diantaranya adalah petani yang tidak memiliki tanah sendiri atau petani yang tanah miliknya sangat kecil 
sehingga hasilnya tidak cukup untuk memberi makan keluarganya, kaum buruh yang tidak terpelajar dan tidak terlatih (unskilled labor), atau golongan ekonomi sangat lemah.

Dimensi berikutnya adalah kemiskinan sistemik.Kemiskinan sistemik adalah kemiskinan yang terjadi karena sekelompok yang kaya dan hidup dalam kemewahan berada dalam kebudayaannya sendiri serta berusaha menguasai dan mengontrol berbagai segi kehidupan baik dari sistem politik, sistem ekonomi, dan sistem sosial yang berlaku di masyarakat.Kelompok ini justru bersifat konservatif dan menyebabkan terjadinya kemiskinan yang sebanyak-banyaknya dan menjadikan segelintir manusia kaya menjadi "raja" dan lainnya menjadi miskin. Kemiskinan sistemik ini sengaja dirancang secara sistematik dan terstruktural agar masyarakat dapat dimiskinkan.

Pemecahan masalah kemiskinan bergantung pada tiga dimensi tersebut dan harus dilakukan secara terintegrasi dan saling berkaitan, yaitu kultural, struktural, dan sistemik (Kasim, 2006). Lipton (2002) menjelaskan bahwa terdapat lima strategi dalam penanggulangan kemiskinan. Pertama adalah reformasi perdagangan. Reformasi pada umumnya hanya memiliki efek sangat sederhana secara langsung dalam mengurangi kemiskinan. Namun, pada sektor-sektor tertentu, dapat berdampak pada upaya penanggulangan kemiskinan, seperti pengendalian liberalisasi beras di Filipina melalui pemberian kompensasi kepada petani. Selain itu investasi infrastruktur seperti akses jalan ke pedasaan juga akan menurunkan tingkat kemiskinan, seperti yang terjadi di Laos.

Kedua, jumlah keluarga yang lebih besar akan meningkatkan kemiskinan, karena akan menurunkan tabungan, menurunkan pendapatan orang tua dan mengurangi akses ke sekolah. Oleh karena itu, harus ada kebijakan negara untuk menekan pertumbuhan penduduk, terutama terhadap penduduk miskin.Ketiga, transfer ke penduduk miskin relatif berhasil, tetapi dengan kesalahan target dan terjadi kebocoran. Hal ini terjadi pada skema zakat diPakistan dan skema pemberian makanan kerja untuk pekerja di India. Keempat, pinjaman keuangan mikro yang didasarkan pada konsep dari seleksi mandiri antara yang miskin yang ingin meminjam, dapat memiliki dampak positif pada sejumlah moneter dan indikator kesejahteraan, seperti terjadi di Pakistan.
Kelima, petani kecil harus diberikan akses ke pasar untuk berperan dalam rantai pasokan global. Seperti di Thailand, tanaman niche organik milik petani kontrak ditampilkan dan lebih menguntungkan daripada petani konvensional yang berbasis di pasar.

Untuk itu, strategi penanggulangan kemiskinan dan pembangunan kesejahteraan sosial haruslah bersifat jangka panjang, terarah, serta terfokus pada sektor pendidikan dan kesehatan. Strategi penanggulangan kemiskinan yang tepat dapat dilihat dari ketepatan kebijakan yang diambil oleh pemerintah suatu negara. Secara umum, kebijakan ekonomi makro yang diambil oleh pemerintah sudah tepat guna meningkatkan akses penduduk miskin terhadap sumber daya produktif dan pasar. Bilamana terjadi permasalahan dalam sistem ekonomi lapisan penduduk miskin, pemerintah harus melakukan reorientasi kebijakan anti kemiskinan.

Jazairi (1992: 213-214) menguraikan tiga hal yang dapat dilakukan untuk penyesuaian suatu kebijakan anti kemiskinan, sebagai berikut: Kebijakan nasional dalam bidang perpajakan dan pengeluaran, keuangan, kredit dan tingkat bunga, kebijaksanaan harga dan pemasaran, dan nilai tukar uang, perlu terus menerus dikaji ulang untuk mengidentfikasi kawasan-kawasan kebijakan yang menghambat sektor ekonomi lapisan penduduk miskin; Lembaga-lembaga sosial ekonomi pada berbagai jenjang juga perlu terus-menerus ditinjau ulang untuk melayani kepentingan penduduk miskin lebih efektif: Sejumlah kebijakan nasional juga diperlukan untuk meningkatkan aliran sumber daya dari luar bagi lapisan penduduk miskin dan untuk mengeliminasi distorsi perdagangan barangbarang yang menyangkut kepentingan mereka.

Pada aspek kemiskinan desa-kota, kebijakan-kebijakan juga harus disesuaikan dengan kondisi kemiskinan pada wilayah desa-kota. Lipton (1992) menyatakan bahwa sumber kemiskinan di negaranegara berkembang berakar dari kebijakan pembangunan kota yang bias. Lipton melihat kebijakan redistribusi kota-desa (urban rural reditribution) sebagai kebijakan yang paling penting dari empat pilihan kebijakan yang mungkin diambil oleh pemerintah negara-negara berkembang. Keempat pilihan kebijakan tersebut adalah (1) kebijakan percepatan pertumbuhan ekonomi plus mekanisme "tetesan ke bawah" (trikcle- 
down); (2) Kebijakan reditribusi di lingkungan pedesaan (intra rural redsitribution); (3) kebijakan pertumbuhan khusus penduduk miskin di daerah pedesaan; dan (4) kebijakan redistribusi desa-kota.

Huraerah (2011) menguraikan strategi yang harus dilakukan untuk mengatasi kemiskinan adalah 1) strategi multidimensional, 2) peningkatan kemampuan dasar masyarakat miskin melalui pendidikan, kesehatan, keterampilan usaha, teknologi, perluasan jaringan kerja, serta informasi pasar; 3) pelibatan masyarakat miskin dalam keseluruhan proses penanggulangan kemiskinan mulai dari perencanaan, pelaksanaan, pengawasan dan evaluasi, bahkan pada proses pengambilan keputusan, dan 4) pemberdayaan. Hal senada juga disampaikan oleh Jajang (2013) bahwa,

kebijakan untuk mengurangi jumlah penduduk miskin adalah meningkatkan pertumbuhan ekonomi, mengembangkan pendidikan, pengendalian jumlah penduduk serta transformasi tenaga kerja dari sektor pertanian ke sektor industri, perdagangan, dan jasa.

\section{Metode Penelitian}

Jenis dan pendekatan penelitian kualitatif ini adalah eksploratif.Penelitian kualitatif digunakan untuk memperoleh gambaran yang mendalam tentang karakteristik kemiskinan serta kebijakan penanggulangannya di Sidoarjo. Pemilihan Kabupaten Sidoarjo sebagai lokus penelitian karena, pertama, tingkat kemiskinan di daerah ini termasuk rendah di Jawa Timur dengan pengalokasian anggaran yang cukup besar meski penurunan tingkat kemiskinan setiap tahunnya tidak sebanding dengan anggaran yang dikeluarkan pemerintah Kabupaten Sidoarjo. Kedua, capaian kinerja penanggulangan kemiskinan di Sidoarjo juga diapresiasi oleh pemerintah pusat dengan penghargaan pro poor award pada tahun 2011 dan 2012.

Pengumpulan data primer dilakukan melalui wawancara mendalam terhadap informan dari masyarakat maupun dari pemerintah daerah Kabupaten Sidoarjo.Agar wawancara dalam upaya penggalian data mendapatkan hasil yang optimal, peneliti menyusun dan menggunakan interview guide. Hasil wawancara kemudian ditranskrip, ditranlate, dikoding, dan dianalisis.Data sekunder penelitian diperoleh dari dokumen rencana strategi pembangunan jangka panjang, menengah, maupun rencana kerja daerah di tingkat satuan kerja perangkat daerah (SKPD). Teknik penganalisisan yang digunakan adalah grounded yang dikonstruksikan Strauss \& Corbin (1990) melalui coding, yakni open coding, axial coding, selective coding, dan simpulan verifikasi.

\section{Kemiskinan dan Karakteristiknya di Kabupaten Sidoarjo}

Perkembangan kemiskinan suatu daerah yang dilihat dari jumlah jiwa yang miskin bertujuan untuk intervensi program agar tepat sasaran.Untuk melihat kinerja daerah dalam menurunkan kemiskinan, perkembangan kemiskinan dapat dilihat dari data angka kemiskinan. Perkembangan angka kemiskinan Kabupaten Sidoarjo Tahun 2006 sampai dengan 2011 disajikan dalam bentuk grafik sebagaimana Gambar 1 berikut:

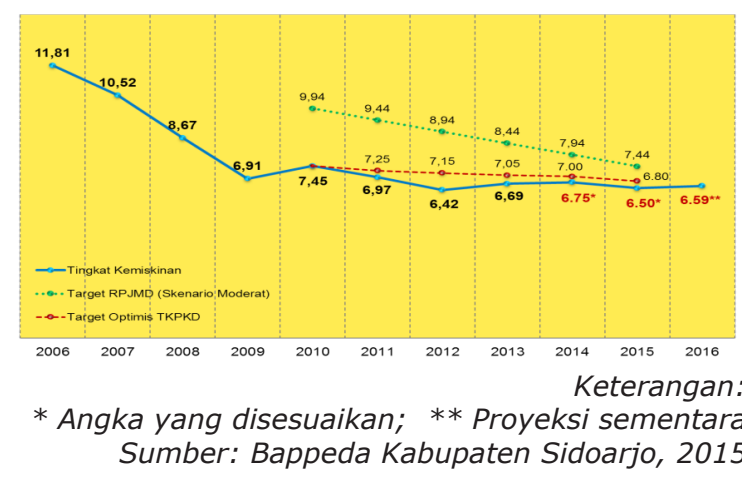

Gambar 1

Grafik Perkembangan Angka Kemiskinan Kabupaten Sidoarjo Tahun 2006 s.d. 2013 dan Proyeksi Tahun 2014 s.d 2016

Dari Gambar 1 tersebut dapat dilihat bahwa perkembangan angka kemiskinan di Kabupaten Sidoarjo mulai tahun 2006 sampai dengan tahun 2009 mengalami trend penurunan, tetapi pada tahun 2010 mengalami kenaikan sekitar 0,5\%. Kemudian pada tahun 2011 s.d 2013 cenderung kembali mengalami penurunan. Bahkan pencapaiannya jauh di bawah target dalam RPJMD dan melampaui target optimis dari Tim Koordinasi Penanggulangan Kemiskinan Daerah (TKPKD).

Penyebaran jumlah rumah tangga penduduk miskin Kabupaten Sidoarjo pada masing-masing kecamatan, persentase tertinggi untuk rumah tangga dengan kondisi kesejahteraan $\leq 30 \%$ terendah terdapat di Kecamatan Jabon sebesar 49,17\% di ikuti dengan Kecamatan Tarik sebesar 48,41\%, kemudian Kecamatan Krembung, Kecamatan Balongbendo dan Kecamatan Wonoayu 
masing-masing sebesar 43,73\%, 40,98\% dan $31,26 \%$. Sedangkan Kecamatan dengan persentase rumah tangga terendah terdapat di Kecamatan Sedati yaitu sebesar 5,21\%, sebagaimana disajikan pada Gambar 2 di bawah ini:

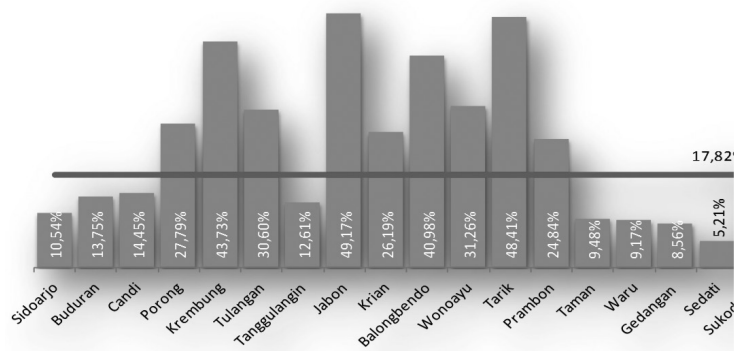

Gambar 2: Persentase Rumah Tangga pada Kelompok 1,2 dan 3 masing-masing Kecamatan Sumber : SPPKD Kabupaten Sidoarjo, Tahun 2014

Persoalan kemiskinan bukan hanya sekadar berapa jumlah dan persentase penduduk miskin. Dimensi lain yang perlu diperhatikan adalah tingkat kedalaman dan keparahan kemiskinan. Selain upaya memperkecil jumlah penduduk miskin, kebijakan penanggulangan kemiskinan juga terkait dengan bagaimana mengurangi tingkat kedalaman dan keparahan kemiskinan.

Indeks Kedalaman Kemiskinan (P1) merupakan ukuran rata-rata kesenjangan pengeluaran masing-masing penduduk miskin terhadap garis kemiskinan.Semakin tinggi nilai indeks, semakin jauh rata-rata pengeluaran penduduk dari garis kemiskinan. Perkembangan Indeks Kedalaman Kemiskinan

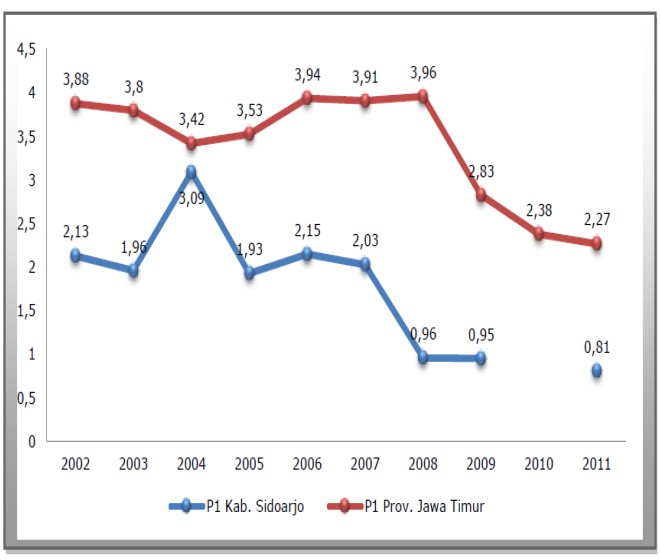

Gambar 3

Perkembangan Indeks Kedalaman Kemiskinan (P1) Kabupaten Sidoarjo terhadap Provinsi Jawa Timur

Tahun 2002 s.d 2011
(P1) Kabupaten Sidoarjo terhadap Propinsi Jawa Timur tahun 2002-2011 disajikan dalam bentuk grafik pada Gambar 3. Indeks Keparahan Kemiskinan (P2) memberikan gambaran mengenai penyebaran pengeluaran di antara penduduk miskin.Semakin tinggi nilai indeks keparahan, semakin tinggi pula ketimpangan pengeluaran di antara penduduk miskin.

Berikut ini ditampilkan perkembangan Indeks Keparahan Kemiskinan (P2) penduduk Kabupaten Sidoarjo terhadap Propinsi Jawa Timur Tahun 2002-2011 dalam bentuk grafik pada Gambar 4.

Dari gambar di atas dapat dilihat bahwa posisi Indeks Kedalaman Kemiskinan (P1) dan Indkes Keparahan Kemiskinan Kabupaten Sidoarjo mulai kurun waktu tahun 2002 sampai dengan tahun 2011 terus berada di bawah posisi Indeks Kedalaman Kemiskinan (P1) Provinsi Jawa Timur. Hal ini menunjukkan bahwa ukuran rata-rata pengeluaran masingmasing penduduk miskin di Kabupaten Sidoarjo berada pada tingkat kesenjangan yang cukup rendah bila dibandingkan dengan Provinsi Jawa Timur.

Agar pelaksanaan program penanggulangan kemiskinan tepat sasaran dan sesuai dengan yang berhak menerima, pemerintah Kabupaten Sidoarjo menggunakan ketepatan data masyarakat miskin yang dimiliki Biro Pusat Statistik Sidoarjo dan karakteristik masyarakat miskin penerima manfaat. Ketepatan data masyarakat miskin memiliki arti penting bagi pemerintah dalam program

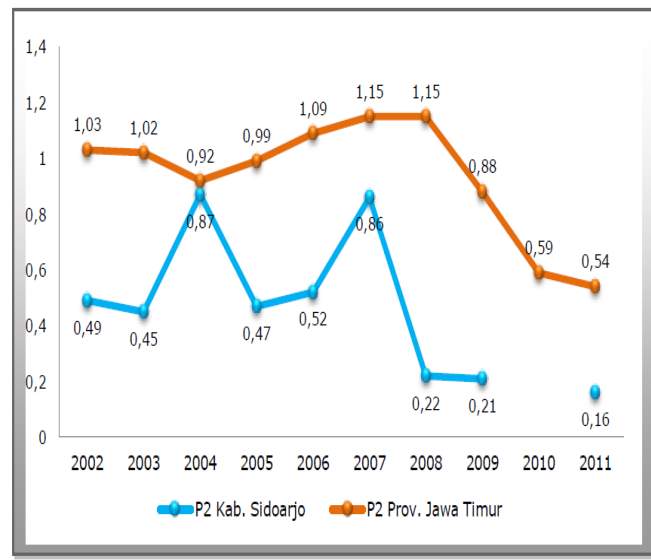

Gambar 4

Perkembangan Indeks Kedalaman Kemiskinan (P2) Kabupaten Sidoarjo terhadap Provinsi Jawa Timur Tahun 2002 s.d 2011

Sumber: BPS, 2014 
penanggulangan kemiskinan.Jika tidak tepat datanya, penanggulangannya pun dapat menjadi tidak tepat sasaran.Begitu halnya dengan karakteristik kemiskinan juga menjadi perhatian dalam program penanggulangannya.

Berdasarkan karakter kemiskinan, kemiskinan di Sidoarjo dapat dilihat dari karakteristik wilayah, yaitu wilayah perdesaan dan perkotaan. Wilayah perkotaan Kabupaten Sidoarjo berada pada sepanjang jalan arteri Surabaya - Malang, mulai utara, tengah, hingga ke selatan.Potensi ekonomi di daerah perkotaan ini terdiri dari industri, perdagangan, dan jasa. Perkotaan yang berada di jalur timur tengah dan timur selatan memiliki potensi ekonomi berupa perikanan. Untuk potensi ekonomi pertanian berada di wilayah barat.

Berdasarkan karakteristik wilayah tersebut, di Sidoarjo tidak tedapat kemiskinan natural maupun struktural.Namun bila dilihat dari persebaran masyarakat miskin yang berada di wilayah urban dan rural, dikhawatirkan masyarakat miskin di Kabupaten Sidoarjo termasuk kemiskinan kultural. Kemiskinan kultural adalah kemiskinan yang terjadi karena malas, tidak disiplin, boros.

Baswir (1997) menyatakan bahwa kemiskinan kultural mengacu pada sikap hidup seseorang atau kelompok masyarakat yang disebabkan oleh gaya hidup, kebiasaan hidup, dan budaya perasaan yang serba berkecukupan dan tidak merasa kekurangan. Kelompok masyarakat seperti ini tidak mudah untuk diajak berpartisipasi dalam pembangunan, tidak mau berusaha untuk memperbaiki dan mengubah tingkat kehidupannya.Akibatnya tingkat pendapatan mereka rendah menurut ukuran yang dipakai secara umum.

Miskin kultural yang diungkapkan oleh Baswir (1997) tersebut dapat dialami oleh sebagian besar masyarakat Sidoarjo baik di pedesaan maupun di perkotaan. Banyaknya Konversi lahan pertanian ke non-pertanian, mendorong masyarakat untuk menjual lahan pertaniannya yang sangat produktif, dengan harapan untuk bekerja pada sektor non pertanian guna mewujudkan kehidupan yang layak. Namun kenyataanya lain, sebagaimana hasil penelitian Sangadji (2002) bahwa "masyarakat Kabupaten Sidoarjo memiliki motivasi yang kuat untuk menjual lahan pertaniannya, tetapi hasil penjualan lahan digunakan untuk keperluan konsumtif, sehingga kemampuan ekonomi masyarakat menurun pasca-konversi lahan pertanian."

Oleh karena keterbatasan kegiatan ekonomi di wilayah pedesaan akibat alih fungsi lahan, masyarakat pedesaan berupaya mengakses lapangan pekerjaan di wilayah perkotaan, sebagaimana diuraikan oleh Lipton (1992) sebagai berikut:

"Orang berurbanisasi merupakan refleksi dari gejala kemacetan ekonomi di desa yang dicirikan dengan sulitnya mencari lowongan pekerjaan dan fragmentasi lahan (sebagai faktor pendorong), serta daya tarik kota dengan penghasilan tinggi (sebagai faktor penarik). Faktor pendorong(push factors) dan faktor penarik (pull factors) sama-sama menjadi determinan penting dalam proses urbanisasi tersebut. Urbanisasi sebetulnya menjadi pilihan yang rasional bagi penduduk desa dalam usaha mendapatkan pendapatan yang lebih baik."

Penjelasan Lipton tersebut, dalam implementasinya, menurut Sudjatmoko (2003), justru urban dipandang rendah, sumber malapetaka kota seperti kejahatan, pelacuran, dan kekotoran. Demikian pula Khudori (2008), menggambarkan kaum miskin kota sebagai warga kota yang tidak memiliki keterampilan dan pengetahuan menunjukkan bahwa peluang yang dimiliki oleh kaum miskin kota berada pada sektor informal. Sektor informal sering kali dikaitkan dengan kaum miskin kota yang tidak terdidik sehingga kaum miskin tersebut hanya mampu bekerja di sektor informal yang tidak membutuhkan keahlian khusus.

\section{Kebijakan dan Program Penanggulangan Kemiskinan}

Penanggulangan kemiskinan merupakan salah satu prioritas program pembangunan di Kabupaten Sidoarjo. Strategi penanggulangannya adalah meningkatkan kualitas sumber daya manusia melalui pendidikan, kesehatan, dan pendapatan masyarakat. Kebijakan umum yang digunakan, seperti yang tertera dalam dokumen Rencana Pembangunan Jangka Menengah Kabupaten Sidoarjo, adalah peningkatan tingkat pendidikan, tingkat kesehatan, daya saing sumber daya manusia, daya beli masyarakat, dan pengendalian laju pertumbuhan penduduk.

Karena program penanggulangan kemiskinan di Kabupaten Sidoarjo cukup banyak jumlahnya, peneliti hanya menjelaskan ketepatan sasaran program penanggulangan dari lima program sebagai benchmark, yaitu bantuan khusus siswa miskin (BKSM), jaminan kesehatan daerah (jamkesda), beras miskin (raskin), rumah tidak layak huni 
(RTLH), dan dana bergulir. Kelima program tersebut merupakan program perlindungan sosial yang dibutuhkan masyarakat miskin guna memenuhi kebutuhan dasarnya. Adapun sasaran atau penerima manfaat dari kelima program tersebut secara garis besar dirangkum dalam Tabel 1.

Dari kelima program penanggulangan kemiskinan yang dilaksanakan oleh Pemerintah Kabupaten Sidoarjo, program RTLH dan Dana Bergulir termasuk program yang memiliki ketepatan sasaran meski dananya terlalu minim. Program RTLH, misalnya, Pemerintah Kabupaten Sidoarjo melalui Badan Pemberdayaan Masyarakat, Perempuan dan Keluarga Berencana (BPMPKB) Kabupaten Sidoarjo memberikan bantuan dana kepada warga miskin sejumlah Rp. 6.000.000,setelah dipotong pajak.

Jumlah anggaran tersebut memang sangat kecil dibandingkan dengan total anggaran yang dibutuhkan untuk rehab rumah tidak layak huni. Dana tersebut hanya sebagai stimulan bagi warga miskin untuk merehap rumahnya yang tidak layak huni. Seperti disampaikan oleh Ibu Kariyati, warga RT 023 RW 004 Kelurahan Lemah Putro, penerima bantuan RTLH tahun 2011, sebagai berikut:

"... ya masalahe kan dana yang didapat itu sedikit, cuma enam juta jadi kekurangan dana biyen iku, wong entek'e ae hampir dua puluh empat juta mas, iku ae warga ken ewes gotong royong mbantu kabeh, soale omah e gedek parah wes".

("...ya masalahnya dana yang diperoleh sedikit, hanya enam juta rupiah. Jadi, dananya kurang. Anggaran rehab rumah saja menghabiskan Rp. 24 juta. Itu pun semua warga bergotong royong untuk membantu, soalnya rumahnya memakai bahan pelepah bambu dan kondisinya sangat parah").

(Sumber: Hasil Wawancara dengan Ibu Kariyati di Kelurahan Lemah Putro, Maret 2015)

Kendala pelaksanaan program rehab RTLH tidak hanya jumlah bantuan yang minim, tetapi juga proses pelaksanaan program tersebut terkesan dipaksakan, seperti dikatakan oleh Pak Syamsul Munir, warga RT 004 RW 002 Kelurahan Magersari Kecamatan Sidoarjo, sebagai berikut:

"... kendalanya ya uangnya itu ndak cukup, lah sekarang bahan bangunan saja mahal kalau uangnya segitu ya ndak cukup.Apalagi dulu itu waktu terima uang harus cepet-cepet dibangun buat laporan pemerintah, jadi ya kebingungan nyari uang tambahan. Ndak ada proses sosialisasi, pokoknya dipilih aparat desa, terus beberapa bulan kemudian nerima uang gitu".

(Sumber : Hasil Wawancara dengan P.Syamsul Munir, Kelurahan Magersari, 18 Maret 2015)
Terkait dengan beberapa kendala pelaksanaan bantuan rehab RTLH, Kepala Bidang Penanggulangan Kemiskinan BPMKB Kabupaten Sidoarjo, Ir. Rosida Winayu, MM, menjelaskan sebagai berikut:

\begin{abstract}
"Jumlah bantuan keuangan rehab RTLH adalah tujuah juta rupiah per unit, kemudian dipotong pajak, sehingga yang diterima oleh penerima kurang lebih enam juta rupiah. Bantuan yang diberikan ini sifatnya hanya menstimulasi masyarakat yang mampu untuk ikut berpartisipasi kepada warga miskin yang kurang mampu". (Sumber: Hasil wawancara dengan Ir. Rosida Winayu, MM, di BPMPKB, 20 Maret 2015)
\end{abstract}

Sedangkan program BKSM, Jamkesda dan Raskin, penerima manfaatnya belum seluruhnya dinikmati oleh semua masyarakat miskin.

Program BKSM. Berdasarkan Pedoman Teknis BKSM, disebutkan bahwa sasaran program BKSM adalah siswa jenjang SMA/ SMK Negeri dan Swasta di Jawa Timur yang berasal dari keluarga tidak mampu. Pada tataran implementasi program, ternyata ada beberapa siswa yang menerima BKSM berasal dari keluarga yang mampu, karena bertempat tinggal di perumahan menengah ke atas. Demikian pula siswa penerima BKSM ada yang berasal dari daerah luar Kabupaten Sidoarjo, seperti Kabupaten Gresik, Kabupaten Mojokerto, Kabupaten Pasuruan dan Kota Surabaya. Bahkan ada siswa penerima BKSM Sidoarjo berasal dari Kabupaten Nganjuk dan Kediri. Sasaran penerima BKSM yang salah ini berawal dari perekrutan calon penerima yang tidak cermat. Sekolah diberi kewenangan penuh untuk mengusulkan siswa calon penerima BKSM, tanpa diverifikasi lagi oleh Dinas Pendidikan. Yang diverifikasi Dinas Pendidikan adalah sebatas pada jumlah siswa calon penerima dari masing-masing satuan pendidikan, verifikasi data tidak sampai kepada latar belakang ekonomi dan alamat tempat tinggal siswa yang diusulkan satuan pendidikan untuk menerima BKSM. Akibatnya, anggaran yang dialokasikan Pemerintah Kabupaten Sidoarjo untuk program BKSM tidak semuanya dapat dinikmati oleh masyarakat miskin Sidoarjo.

Program Jamkesda. Seperti halnya program BKSM, penerima manfaat program Jamkesda juga ada yang salah sasaran. Masih ditemukan adanya kepesertaan Jamkesda berasal dari keluarga yang mampu, sebaliknya ada masyarakat yang kurang mampu tidak masuk kepesertaan Jamkesda. Hal ini disebabkan oleh proses pendataan masyarakat miskin yang dilakukan oleh Badan Pusat Statistik (BPS). Kriteria atau variabel 
Tabel 1

Ringkasan Ketepatan Sasaran Pelaksanaan BKSM, Jamkesda, Raskin, RTLH dan Dana Bergulir di Kabupaten Sidoarjo

\begin{tabular}{|c|c|c|c|c|}
\hline No. & Program & Kelompok Sasaran & Penerima Manfaat & Penjelasan \\
\hline 1 & 2 & 3 & 4 & 5 \\
\hline 1. & BKSM & $\begin{array}{l}\text { Kelompok masyarakat } \\
\text { pada klaster } 1 \text { yaitu } \\
\text { sangat miskin dan } \\
\text { miskin }\end{array}$ & $\begin{array}{l}\text { a. Penerima tidak hanya } \\
\text { siswa miskin, tetapi juga non } \\
\text { miskin (bertempat tinggal } \\
\text { di perumahan menengah ke } \\
\text { atas) } \\
\text { b. Penerima ada yang berasal } \\
\text { dari luar Kabupaten Sidoarjo }\end{array}$ & $\begin{array}{l}\text { a. Data siswa yang diusul- } \\
\text { kan oleh sekolah ada yang } \\
\text { tidak tepat } \\
\text { b. Data tidak diverifikasi oleh } \\
\text { Dinas Pendidikan } \\
\text { c. Data yang digunakan tidak } \\
\text { berdasarkan pada bank data } \\
\text { kemiskinan hasil PPLS } 2008 \\
\text { atau PPLS } 2011 \text {. }\end{array}$ \\
\hline 2. & Jamkesda & $\begin{array}{l}\text { Kelompok masyarakat } \\
\text { pada klaster } 1 \text { dan } \\
2 \text { dan } 3 \text { yaitu sangat } \\
\text { miskin, miskin, hampir } \\
\text { miskin dan rentan } \\
\text { miskin }\end{array}$ & $\begin{array}{l}\text { a. Pemanfaatan Jamkesda } \\
\text { tidak hanya masyarakat } \\
\text { miskin, tetapi juga dinimati } \\
\text { oleh masyarakat yang mampu } \\
\text { b. Masih terdapat masyarakat } \\
\text { yang belum menerima } \\
\text { Jamkesda }\end{array}$ & $\begin{array}{l}\text { a. Sebagian data tidak } \\
\text { sesuai dengan kondisi yang } \\
\text { sebenarnya (tidak valid); } \\
\text { b. Masyarakat yang mampu } \\
\text { secara ekonomi, karena } \\
\text { penyakit yang diderita cukup } \\
\text { lama dan membutuhkan } \\
\text { biaya besar, sehingga } \\
\text { menjadi miskin. }\end{array}$ \\
\hline 3. & Raskin & $\begin{array}{l}\text { Kelompok masyarakat } \\
\text { pada klaster } 1 \text { yaitu } \\
\text { sangat miskin dan } \\
\text { miskin }\end{array}$ & $\begin{array}{l}\text { a. Penerima Raskin tidak } \\
\text { hanya masyarakat miskin } \\
\text { b. Masih ada warga miskin } \\
\text { yang belum menerima Raskin } \\
\text { c. Jumlah beras yang diterima } \\
\text { tidak utuh, karena harus } \\
\text { dibagi pada masyarakat } \\
\text { miskin yang tidak masuk data } \\
\text { penerima Raskin } \\
\text { d. Kualitas beras kurang bagus }\end{array}$ & $\begin{array}{l}\text { a. Sebagian data tidak } \\
\text { sesuai dengan kondisi yang } \\
\text { sebenarnya (tidak valid); } \\
\text { b. Kebijakan camat } \\
\text { dan kepala desa untuk } \\
\text { mengurangi jatah Raskin } \\
\text { untuk dibagikan kepada } \\
\text { masyarakat miskin yang } \\
\text { belum terdata }\end{array}$ \\
\hline 4. & 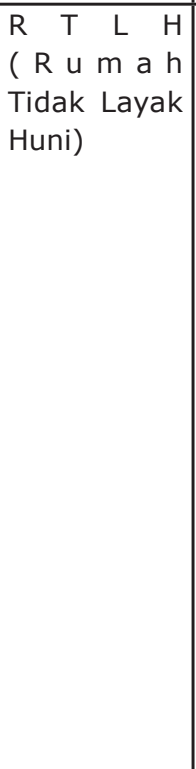 & $\begin{array}{l}\text { Kelompok masyarakat } \\
\text { pada klaster } 2 \text { yaitu } \\
\text { hampir miskin }\end{array}$ & $\begin{array}{l}\text { a. Masyarakat yang memiliki } \\
\text { rumah tidak layak huni } \\
\text { dan tidak mampu untuk } \\
\text { memperbaiki rumahnya ; } \\
\text { b. Bantuan berfungsi sebagai } \\
\text { stimulan, sisanya merupakan } \\
\text { partisipasi masya-rakat } \\
\text { c. Status lahan yang ditempati } \\
\text { harus milik sendiri. }\end{array}$ & $\begin{array}{l}\text { a. Terdapat rumah warga } \\
\text { miskin yang diusulkan oleh } \\
\text { Kepala Desa atau camat } \\
\text { membutuhkan perbaikan } \\
\text { cukup besar, sehingga } \\
\text { partisipasi masyarakat } \\
\text { cukup besar karena jumlah } \\
\text { bantuan yang diberikan oleh } \\
\text { Pemda sama untuk setiap } \\
\text { rumah, yaitu tanpa melihat } \\
\text { besar kecilnya dana yang } \\
\text { dibutuhkan untuk perbaikan } \\
\text { rumah tersebut. } \\
\text { b. Belum ada mekanisme } \\
\text { pemberian bantuan } \\
\text { kepada warga miskin yang } \\
\text { menempati aset atau lahan } \\
\text { bukan atas namanya, tetapi } \\
\text { tercatat sebagai warga desa } \\
\text { yang bersangkutan. }\end{array}$ \\
\hline 5. & 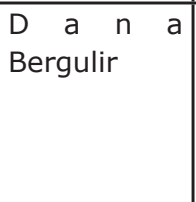 & $\begin{array}{l}\text { Kelompok masyarakat } \\
\text { pada klaster } 3 \text { yaitu } \\
\text { rentan miskin }\end{array}$ & $\begin{array}{l}\text { a. UMKM; } \\
\text { b. Masyarakat yang belum } \\
\text { memiliki pekerjaan tetap }\end{array}$ & $\begin{array}{l}\text { Penerima dana bergulir } \\
\text { tidak dievaluasi dan dibina } \\
\text { lebih lanjut sehingga masih } \\
\text { terdapat penerima yang tidak } \\
\text { melanjutkan usahanya. }\end{array}$ \\
\hline
\end{tabular}


yang digunakan BPS, ternyata belum bisa mengakomodir kelompok masyarakat tertentu yang membutuhkan layanan kesehatan. Hal lainnya adalah data yang diberikan oleh Kepala Desa lebih bersifat politik dan mengutamakan unsur kekeluargaan. Padahal Jamkesda adalah program bantuan sosial untuk pelayanan kesehatan bagi masyarakat miskin dan hampir miskin yang tidak masuk dalam kuota Jamkesmas. Tujuan Jamkesda, sama seperti Jamkesmas, yaitu untuk meningkatkan akses terhadap masyarakat miskin dan hampir miskin agar dapat memperoleh pelayanan kesehatan.

Program Raskin. Demikian halnya program BKSM dan Jamkesda, Program Raskin juga masih dikeluhkan oleh masyarakat. Selain kualitasnya yang masih kurang baik, juga jumlah beras yang diterima masyarakat tidak sesuai dengan jumlah yang menjadi jatahnya. Untuk Raskin yang berasal dari APBD, setiap KK harusnya mendapat $10 \mathrm{Kg}$ setiap bulannya. Oleh karena harus dibagi ke mayarakat miskin yang belum masuk data penerima Raskin, setiap KK hanya diberikan $7 \mathrm{~kg}$, sisanya $3 \mathrm{Kg}$ dikumpulkan dan diberikan kepada warga yang belum masuk dalam data penerima Raskin. Kebijakan ini adalah hasil dari komunikasi camat dengan kepala desa dan kepala Rukun Tetangga (RT)/Rukun Warga (RW). Raskin merupakan subsidi pangan yang diperuntukkan bagi keluarga miskin sebagai upaya dari pemerintah untuk meningkatkan ketahanan pangan dan memberikan perlindungan pada keluarga miskin. Keberhasilan Program Raskin diukur berdasarkan tingkat pencapaian indikator 6T, yaitu: tepat sasaran, tepat jumlah, tepat harga, tepat waktu, tepat kualitas, dan tepat administrasi. Program ini bertujuan untuk mengurangi beban pengeluaran Rumah Tangga Sasaran (RTS) melalui pemenuhan sebagian kebutuhan pangan pokok dalam bentuk beras dan mencegah penurunan konsumsi energi dan protein. Selain itu raskin bertujuan untuk meningkatkan/membuka akses pangan keluarga melalui penjualan beras kepada keluarga penerima manfaat dengan jumlah yang telah ditentukan.

Berdasarkan uraian penjelasan ketiga program perlindungan sosial tersebut di atas, dalam pelaksanaannya, secara umum, diharapkan sesuai dengan tujuan pemberian program perlindungan sosial kepada masyarakat, yaitu melakukan pemenuhan hak dasar, pengurangan beban hidup dan perbaikan kualitas hidup masyarakat miskin. Pelaksanaan program dan kegiatan penanggulangan kemiskinan tersebut tersebar di 12 SKPD dan instansi yang dikoordinasikan oleh Tim Koordinasi Penanggulangan Kemiskinan Daerah (TKPKD) Kabupaten Sidoarjo melalui rapat koordinasi dan monitoring lapangan.

Jumlah program penanggulangan kemiskinan yang dilaksanakan oleh pemerintah Kabupaten Sidoarjo sebanyak 59 program adalah cukup banyak, namun demikian diharapkan tidak hanya penekanan pada jumlah program, tetapi yang lebih penting juga adalah kualitas programnya sehingga dapat dirasakan oleh masyarakat miskin, terutama pelayanan dan kebutuhan dasar masyarakat miskin, yaitu pendidikan, kesehatan, pangan, dan perumahan yang layak serta pengembangan ekonomi masyarakat.

\section{Simpulan dan Saran}

Sejumlah simpulan dan saran artikel ini adalah sebagai berikut: Penanggulangan kemiskinan harus didasarkan pada karakteristik masyarakat miskin dan wilayah. Karakteristik wilayah di Kabupaten Sidoarjo terbagi dalam wilayah perdesaan dan perkotaan. Bberdasarkan karakteristik wilayah tersebut, kemiskinan yang ada di Kabupaten Sidoarjo termasuk kategori kemiskinan kultural.

Kebijakan umum penanggulangan kemiskinan di Kabupaten Sidoarjo diantaranya adalah peningkatan tingkat pendidikan masyarakat, derajat kesehatan masyarakat, daya saing sumber daya manusia, daya beli masyarakat, dan pengendalian laju pertumbuhan penduduk.

Pelaksanaan program dan kegiatan penanggulangan kemiskinan di Kabupaten Sidoarjo masih belum optimal, terutama program BKSM, jamkesda, dan raskin. Untuk program rumah tidak layak huni (RTLH) dan dana bergulir termasuk efektif dan tepat sasaran.

Peran dokumen Strategi Penanggulangan Kemiskinan sebagai instrumen yang mengarahkan dan mengendalikan program dan kegiatan sektoral untuk penanggulangan kemiskinan belum dioptimalkan.

Dalam tahap pengorganisasian pelaksanaan program penanggulangan kemiskinan yaitu melalui pembantukan TKPKD, tidak semua pemangku kepentingan dilibatkan di dalam susunan organisasi TKPKD; Monitoring dan evaluasi yang dilakukan terhadap pelaksanaan program 
penanggulangan kemiskinan, lebih sering melalui rapat-rapat koordinasi. Padahal keberhasilan pelaksanaan suatu program penanggulangan kemiskinan dipantau secara langsung pada sasaran atau penerima manfaat.

Saran yang ditawarkan terkait dengan alternatif kebijakan dan solusi praktis dapat dilakukan oleh Pemerintah Kabupaten Sidoarjo, sebagai berikut: Pentingnya menyusun Renstra Penanggulangan Kemiskinan sebagai acuan dalam perencanaan dan penganggaran program penanggulangan kemiskinan.

Perlu adanya Perda yang mengatur mekanisme atau prosedur perencanan dan penganggaran, sehingga inkonsistensi perencanaan dan penganggaran dapat diminimalisasi dan diharapakn peran stakeholder dalam perencanaan dan penganggaran lebih bersifat simetris.

Lebih dioptimalkan lagi peran TKPKD dalam pengoordinasian pelaksanaan program pe-nanggulangan kemiskinan, terutama dalam mengendalikan ketepatan sasaran atau penerima manfaat dari program penanggulangan kemiskinan.

Dalam mengalokasikan anggaran untuk masing-masing program penanggulangan kemiskinan, hendaknya dimatangkan lebih dulu kinerja yang akan dicapai, sehingga outcome yang akan dihasilkan oleh sebuah program diharapkan sesuai dengan jumlah anggaran yang dibelanjakan.

Dalam rangka pengelolaan keuangan secara ekonomis, efisien dan ekonomis, maka sebaiknya sejak awal perencanaan, program tersebut dianalisis kemanfaatannya dan kebutuhan anggarannya. Selain itu, dalam tahap pelaksanaan, pengendalian harus selalu dilakukan.

\section{Daftar Pustaka}

Badan Pengawasan Keuangan dan Pembangunan. (2007). Akuntabilitas Instansi Pemerintah, Edisi Kelima.

Badan Pusat Statistik. (2003). Data dan Informasi Kemiskinan 2002 dan 2003. BPS Jakarta.

Baswir, R. (1997). Agenda Ekonomi Kerakyatan. Pustaka Pelajar, Yogyakarta.

Fernanda, D. 2002. "Sistem Perencanaan dan Akuntabilitas Kinerja Pemerintah Daerah" Journal Desentralisasi Volume 1 Nomor1, PusatKajian Kinerja Otonomi Daerah, LAN, Jakarta.

Huraerah, A. (2011). "Kompetensi Pekerjaan
Sosial dalam Penanganan Kemiskinan, Humanitas". Jurnal Ilmu Kesejahteraan Sosial, Volume 4, No.1.

http://www.dprd-sidoarjokab.go.id. 2013. Pemkab dan DPRD Beda Data Soal Angka Kemiskinan" diakses 4 April 2014.

Jajang, dkk. (2013). "Analisis Kemiskinan menggunakan Model Panel Spasial Statik". dalam Mimbar, Vol. 29, No. 2 (Desember, 2013): 195-203 'Terakreditasi' SK Mendikbud, No.040/P/2014, berlaku 18-02-2014 s.d. 18-02-2019. Bandung: LPPM Universitas Islam Bandung.

Kasim, M. (2006).Karakteristik Kemiskinan dan Strategi Penanggulangannya: Studi Kasus Padang Pariaman. Jakarta: Indomedia Global.

Kementrian Negara Perencanaan Pembangunan Nasional/Kepala Bappenas. (2009). Surat Edaran Bersama Kementrian Negara Perencanaan Pembangunan Nasional/ Kepala Badan Perencanaan Pembangunan Nasional dan Menteri Keuangan tanggal 19 Juni 2009 Nomor 0142/M.PPN/06/2009 dan SE1848/MK/2009 perihal Pedoman Reformasi dan Perencanaan Anggaran, Jakarta.

Kementerian Perencanaan Pembangunan Nasional/Bappenas. (2012). Rencana Kerja Pemerintah Tahun 2013. Jakarta.

Kementerian Perencanaan Pembangunan Nasional/Kepala Bappenas. (2010). Peta Jalan Pencapaian Millenium Development Goals (MDGs). Jakarta.

Khudori. (2008). Ironi Negeri Beras, Yogyakarta: Insist Press.

Lincoln, Y\& Guba, E. G. (1985). Naturalistic Inquiry. London-Baverly Hills: Sage Publication Inc. England.

Lipton, M. (1992). Why Poor People Stay Poor: Urban Bias in World Development. London: Temple Smith.

Muhardi Muhardi. (2000). "Pengentasan Kemiskinan dalam Membangun Masyarakat Madani". Mimbar. Volume 16, No. 3, Tahun 2000. Bandung: LPPM Universitas Islam Bandung.

Pemerintah Kabupaten Sidoarjo. (2010). Rencana Pembangunan Jangka Menengah Daerah (RPJMD) Kabupaten Sidoarjo, 2010, Sidoarjo, h.IX-2.

Pemerintah Kabupaten Sidoarjo. (2011). Laporan Pelaksanaan Penanggulangan Kemiskinan Daerah (LP2KD) Kabupaten Sidoarjo, h.85.

Peraturan Presiden Nomor 5 Tahun 2010 tentang Percepatan Penanggulangan Kemiskinan.

Peters, B.G. (1996). The Future of Governing: Four Emerging Models.Lawrence, KS, Kansas University Press.

Radin, B. (2006). Challenging the Performance Movement: Accountability, Complexity, and DemocraticValues. Washington, DC: Georgetown University Press.

Rievenbark, C. W. (2004). Defining Performance 
Budgeting for Local Governmant, Popular Government.

Sahdan, G. (2005). "Menganggulangi Kemiskinan Desa." Artikel-EkonomiRakyat dan Kemiskinan.Yogyakarta.

Strauss, A., \&Corbin, J. (1992). Basic of
Qualitative Research, Grounded Theory, Procedures and Techniques.Sage Publications, New Buy Park, California.

Sudjatmoko. (2003). Dimensi Manusia dalam Pembangunan, Jakarta: LP3ES. 